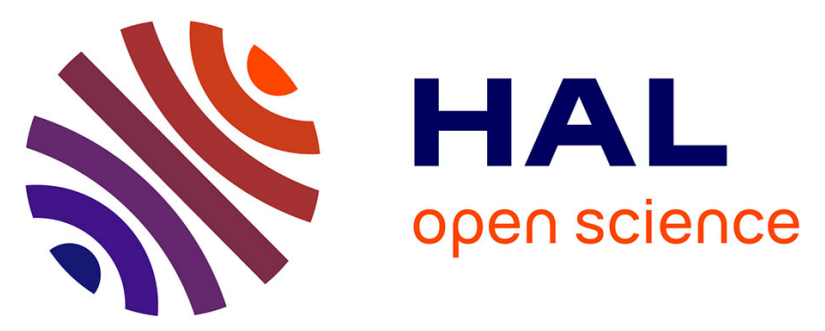

\title{
The role of radical chemistry in the product formation from nitrate radical initiated gas-phase oxidation of isoprene
}

Philip T. M. Carlsson, Luc Vereecken, Anna Novelli, François Bernard, Birger Bohn, Steven S. Brown, Changmin Cho, John Crowley, Andreas

Hofzumahaus, Wahid Mellouki, et al.

\section{To cite this version:}

Philip T. M. Carlsson, Luc Vereecken, Anna Novelli, François Bernard, Birger Bohn, et al.. The role of radical chemistry in the product formation from nitrate radical initiated gas-phase oxidation of isoprene. vEGU21, 2021, Online, France. 10.5194/egusphere-egu21-7338 . insu-03559374

\section{HAL Id: insu-03559374 \\ https://hal-insu.archives-ouvertes.fr/insu-03559374}

Submitted on 7 Feb 2022

HAL is a multi-disciplinary open access archive for the deposit and dissemination of scientific research documents, whether they are published or not. The documents may come from teaching and research institutions in France or abroad, or from public or private research centers.
L'archive ouverte pluridisciplinaire HAL, est destinée au dépôt et à la diffusion de documents scientifiques de niveau recherche, publiés ou non, émanant des établissements d'enseignement et de recherche français ou étrangers, des laboratoires publics ou privés. 


\section{EGU21-7338}

https://doi.org/10.5194/egusphere-egu21-7338

EGU General Assembly 2021

(c) Author(s) 2022. This work is distributed under

the Creative Commons Attribution 4.0 License.

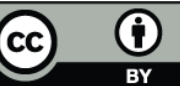

\section{The role of radical chemistry in the product formation from nitrate radical initiated gas-phase oxidation of isoprene}

Philip T. M. Carlsson ${ }^{1}$, Luc Vereecken ${ }^{1}$, Anna Novelli ${ }^{1}$, François Bernard ${ }^{2,6}$, Birger Bohn ${ }^{1}$, Steven S. Brown ${ }^{3,5}$, Changmin Cho ${ }^{1}$, John Crowley ${ }^{4}$, Andreas Hofzumahaus ${ }^{1}$, Abdelwahid Mellouki ${ }^{2}$, David Reimer ${ }^{1}$, Franz Rohrer ${ }^{1}$, Justin Shenolikar ${ }^{4}$, Ralf Tillmann ${ }^{1}$, Li Zhou ${ }^{2,7}$, Astrid Kiendler-Scharr ${ }^{1}$, Andreas Wahner ${ }^{1}$, and Hendrik Fuchs ${ }^{1}$

${ }^{1}$ Institute for Energy and Climate Research, Forschungszentrum Jülich GmbH, Jülich, Germany

${ }^{2}$ Institut de Combustion, Aérothermique, Réactivité et Environnement (ICARE), CNRS (UPR 3021)/OSUC, Orléans, France

${ }^{3}$ NOAA Chemical Sciences Laboratory, Boulder, USA

${ }^{4}$ Atmospheric Chemistry Department, Max-Planck-Institut für Chemie, Mainz, Germany

${ }^{5}$ Department of Chemistry, University of Colorado Boulder, Boulder, USA

${ }^{6}$ now at: Laboratoire de Physique et Chimie de l'Environnement et de l'Espace (LPC2E), Université d'Orléans, Orléans,

France

${ }^{7}$ now at: College of Architecture and Environment, Sichuan University, Chengdu, China.

Experiments at atmospherically relevant conditions were performed in the simulation chamber SAPHIR, investigating the reaction of isoprene with $\mathrm{NO}_{3}$ and its subsequent oxidation. Due to the production of $\mathrm{NO}_{3}$ from the reaction of $\mathrm{NO}_{2}$ with $\mathrm{O}_{3}$ as well as the formation of $\mathrm{OH}$ in subsequent reactions, the reactions of isoprene with $\mathrm{O}_{3}$ and $\mathrm{OH}$ were estimated to contribute up to $15 \%$ of the total isoprene consumption each in these experiments. The ratio of $\mathrm{RO}_{2}$ to $\mathrm{HO}_{2}$ concentrations was varied by changing the reactant concentrations, which modifies the product distribution from bimolecular reactions of the nitrated $\mathrm{RO}_{2}$. The reaction with $\mathrm{HO}_{2}$ or $\mathrm{NO}_{3}$ was found to be the main bimolecular loss process for the $\mathrm{RO}_{2}$ radicals under all conditions examined.

Yields of the first-generation isoprene oxygenated nitrates as well as the sum of methyl vinyl ketone (MVK) and methacrolein (MACR) were determined by high resolution proton mass spectrometry using the Vocus PTR-TOF. The experimental time series of these products are compared to model calculations based on the MCM v3.3.1, ${ }^{1}$ the isoprene mechanism as published by Wennberg et al. $^{2}$ and the newly developed $\mathrm{FZJ-NO}{ }_{3}$-isoprene mechanism, ${ }^{3}$ which incorporates theory-based rate coefficients for a wide range of reactions.

Among other changes, the FZJ- $\mathrm{NO}_{3}$-isoprene mechanism contains a novel fast oxidation route through the epoxidation of alkoxy radicals, originating from the formation of nitrated peroxy radicals. This inhibits the formation of MVK and MACR from the $\mathrm{NO}_{3}$-initiated oxidation of isoprene to practically zero, which agrees with the observations from chamber experiments. In addition, the FZJ- $\mathrm{NO}_{3}$-isoprene mechanism increases the level of agreement for the main first-generation oxygenated nitrates. 
${ }^{1}$ M. E. Jenkin, J. C. Young and A. R. Rickard, The MCM v3.3.1 degradation scheme for isoprene, Atmospheric Chem. Phys., 2015, 15, 11433-11459.

${ }^{2}$ P. O. Wennberg at al., Gas-Phase Reactions of Isoprene and Its Major Oxidation Products, Chem. Rev., 2018, 118, 3337-3390.

${ }^{3}$ L. Vereecken et al., Theoretical and experimental study of peroxy and alkoxy radicals in the NO3-initiated oxidation of isoprene, Phys. Chem. Chem. Phys., submitted. 